\title{
Five new species of the nanoflagellate Pirsonia in the German Bight, North Sea, feeding on planktic diatoms
}

\author{
S. F. Kühn ${ }^{1}$, G. Drebes ${ }^{2}$ \& E. Schnepf ${ }^{3}$ \\ ${ }^{1}$ Alfred-Wegener-Institut für Polar- und Meeresforschung; Am Handelshafen 12, \\ D-27570 Bremerhaven, Germany \\ ${ }^{2}$ Biologische Anstalt Helgoland, Wattenmeerstation Sylt; D-25992 List (Sylt), Germany \\ ${ }^{3}$ Zellenlehre, Fakultät für Biologie, Universität Heidelberg; Im Neuenheimer Feld 230, \\ D-69120 Heidelberg, Germany
}

\begin{abstract}
The structure, development, and host range of five newly detected species of the phagotrophic nanoflagellate Pirsonia are described. They feed on planktic diatoms common in the North Sea: P. verrucosa sp. nov. (on Rhizosolenia delicatula), P. formosa sp. nov. (on Rhizosolenia setigera), $P$. diadema sp. nov. (on Coscinodiscus granii and $C$. wailesii), $P$. eucampiae (on Eucampia zodiacus) and $P$. mucosa sp. nov. (on Rhizosolenia shrubsolei). The occurrence of resting cysts in Pirsonia guinardiae is reported. The impact of Pirsonia on phytoplankton communities is discussed.
\end{abstract}

\section{INTRODUCTION}

Investigators of aquatic ecosystems have put much effort into trying to understand the structure and complexity of pelagic food webs. Factors commonly considered to control the phytoplankton production are the interacting rates of growth and loss due to the effects of physico-chemical conditions, sedimentation, grazing and parasitism (Jewson et al., 1981; Sommer, 1987). Phytoplankton consumers comprise mesozooplankton (e.g. copepods), protozoa (e.g. ciliates), and heterotrophic flagellates. Generally, the predator is much larger than its prey.

There are exceptions to this rule. Suttle et al. (1986) reported on a heterotrophic microflagellate ingesting diatoms up to 6 times longer than the diameter of the flagellate. Pallium feeding allows some dinoflagellates to feed on diatom chains much larger than the predators are themselves (Jacobson \& Anderson, 1986). Various small dinoflagellates ingest the cytoplasm of large diatoms by myzocytosis (Schnepf \& Deichgräber, 1984; Schnepf \& Elbrächter, 1992).

Recently, Schnepf et al. (1990) described the heterotrophic nanoflagellate Pirsonia feeding, by a hitherto unknown strategy, on the marine diatom Guinardia flaccida (Castr.) Peragallo many times its size. The flagellate attaches itself to the frustule and produces a pseudopodium which penetrates into the host cell. This pseudopodium becomes a "trophosome" inside the diatom and gradually phagocytizes the host cytoplasm and digests it in a large food vacuole. The part of the cell body remaining outside of the diatom frustule becomes the "auxosome". It bears the flagella, contains the cell 
organelles and the nucleus but no food vacuoles, and grows during the feeding process. After several divisions of the auxosome the motile stages of Pirsonia are formed.

The systematic position of the flagellate is still uncertain. Palisporomonas seems to have a similiar mode of feeding (De Saedeleer, 1946). The food uptake by chytrids resembles that by Pirsonia, but only superficially. The fungal haustorium resorbs the nutrients "osmotrophically", whereas the Pirsonia trophosome ingests diatom cytoplasm phagocytotically.

In this report we describe five new species of Pirsonia which were isolated from very common and bloom-forming diatoms in the North Sea, namely a Coscinodiscus granii Gough, C. wailesii Gran et Angst, Rhizosolenia setigera Brightwell, $R$. delicatula Cleve, $R$. shrubsolei Cleve and Eucampia zodiacus Ehrenberg (Drebes \& Elbrächter, 1976; Cadée, 1986).

\section{MATERIALS AND METHODS}

The flagellates investigated here were first recognized and isolated by S. F. Kühn (4 species) and G. Drebes (1 species) at different North Sea sites. Most of this work was carried out in autumn 1992 and 1993 on cruises with the "Victor Hensen" in the German Bight. Samples were collected with a 55-um plankton net over the whole water column. About $30 \mathrm{ml}$ of the plankton sample was added to $20 \mathrm{ml} \mathrm{F} / 2$ medium (Guillard \& Ryther, 1962) and was then kept at $6-8{ }^{\circ} \mathrm{C}$ and under low light conditions until further processing in the laboratory (up to 5 days later). As far as possible, microscopic examination was carried out immediately aboard the ship. Even when an infection was not visible at once, it sometimes became apparent after a few days.

Some of the flagellates and diatoms were isolated from plankton samples freshly collected from the Wadden Sea near List (Sylt) with 25- and 80-um plankton nets.

Subsequently, cultures of the Pirsonia species and their host diatoms were established and maintained in Petri dishes in F/2 medium at a $16 \mathrm{~h}$ light to $8 \mathrm{~h}$ dark cycle. Only Guinardia flaccida was kept in Met 44 medium (Schöne \& Schöne, 1982). Twice a week some $\mu l$ of the infected cultures were inoculated into an uninfected host culture. We did not succeed in establishing a quantitatively standardized method for cultivation and inoculation, because both the flagellates and the diatoms vary in their physiological fitness and growth.

The different Pirsonia species were cultivated on Guinardia flaccida (Castr.) Peragallo, Rhizosolenia delicatula Cleve, $R$. pungens Cleve, R. setigera Brightwell, $R$. shrubsolei Cleve, Coscinodiscus granii Gough or C. wailesii Gran et Angst, and Eucampia zodiacus Ehrenberg. The following diatom species were also tested for the host range of Pirsonia: Actinoptychus senarius (Ehrenb.) Ehrenb., Cerataulina pelagica (Cleve) Hendey, Chaetoceros spp., Coscinodiscus concinnus W. Sm., Detonula pumila (Castr.) Schütt, Lauderia annulata Cleve, Leptocylindrus danicus Cleve, Odontella obtusa Kütz., Rhizosolenia stolterfothii H. Peragallo, Stephanopyxis turris (Grev. et Arn.) Ralfs, Thalassionema nitzschioides Grunow, Thalassiosira gravida Cleve, T. punctigera (Castr.) Hasle, and T. rotula Meunier. They were grown under the same conditions described above.

For observations of the living material in Petri dishes we used seawater immersion objectives (Leitz). Flash-light photographs were taken to document the morphology and the development of the organisms. 


\section{RESULTS}

\section{Common characteristics}

The five new flagellates described share so many characteristics with Pirsonia guinardiae (Schnepf et al., 1990) that we can ascribe them without doubt to the same genus. The diagnoses of the new species, therefore, do not include the common characteristics which are given in the diagnosis of the genus (Schnepf et al., 1990).

The motile stages (mature flagellates) are ovoid-elongate. The cell size is in the range of $4-7 \times 7-12 \mu \mathrm{m}$. Generally, cells are hyaline and contain only a few small refractive granules of reserve material within their posterior part. On the ventral side, two flagella are inserted subapically (in P. mucosa in the middle of the cell or even submedianly) and oriented in opposite directions. The anterior flagellum is $10-18 \mu \mathrm{m}$ long; the posterior flagellum is twice or up to 3 times as long. Both flagella move in an undulating way. The movements of the swimming flagellates are slightly jerking, occasionally with abrupt changes in the swimming direction.

When a flagellate is attracted by a diatom, it swims with its ventral side close to the diatom cell (Fig. 6c). The anterior flagellar tip scans the frustule, perhaps testing the compatibility of the diatom as a host. If compatible, the flagellate attaches itself to the diatom, mostly with its posterior end and forms a broad foot, while the flagella are coiled around the apex of the cell (Figs 3a, $4 a, 5 a$ ).

The diatom cell is subsequently invaded by a small pseudopodium which enlarges inside the frustule to become the trophosome (Fig. 2a). This nearly organelle-free part of the flagellate gradually phagocytizes portions of host cytoplasm and digests them in a food vacuole that increases in size. Due to the infection by Pirsonia the organelles of the diatom accumulate at the trophosome. This process facilitates and supports continuous phagocytosis.

The trophosome is connected by a thin and delicate cytoplasmic strand with the auxosome which remains outside the frustule and does not contain food vacuoles. Soon after the feeding process has started, the "primary auxosome" begins to grow. Flagella may or may not be retained at this stage. After reaching its maximum size, the primary auxosome divides (Figs 2b, 4 b). Cytologically it is a longitudinal division, i.e. the division plane runs through the (former) flagellar bases, even when the morphological longitudinal axis of the cell is not identical with the cytological one, or when the cell is globular. This process can be repeated several times.

As long as the newly formed cells remain connected to the trophosome we call them "secondary auxosomes". Usually, the number of divisions depends on the amount of digested host cytoplasm, but it is also species specific. Eventually, "flagellate mother cells" (FMCs) are formed (Fig. 4f). The FMCs sometimes have short flagella, but these are then less mobile. A FMC arises when a cell is cut off from its food supply either (i) when all available diatom cell contents are consumed, (ii) by a transverse or oblique division (with respect to the longitudinal axis), which separates it from the trophosome (this division is an unequal one!), or (iii) by getting pushed away by other growing secondary auxosomes.

Auxosomes and FMCs have conspicuously large amounts of refractive granules of reserve material. By means of one or two equal maturation divisions the flagellates are 
formed from the FMCs. They have to mature before they are fully motile and capable to re-infect successfully. During the maturation process the flagella arise and/or grow to their final length, the cell shape changes from globular to elongate, and the refractive granules are reduced in size and amount (compare Figures $5 \mathrm{~b}$ and $5 \mathrm{~d}$ ).

The trophosome, containing dark-brownish residual bodies, disintegrates soon after the detachment of the FMCs. The residual bodies remain visible inside the diatom cell for a long time and are characteristic of Pirsonia attacks (Fig. 5a).

The diatom cell very rarely survives an attack by Pirsonia (Fig. 5f). In cultures, multiple infections are common, while they are rare in field samples. Only healthy appearing diatoms are infected, whereas cells with disintegrating cytoplasm are not attacked.

So far no sexual stages have been observed in any of the Pirsonia species. Resting cysts were found only in $P$. guinardiae.

\section{Pirsonia guinardiae Schnepf, Drebes et Elbrächter}

(Figs 1a-f)

Pirsonia guinardiae has already been described in detail (Schnepf et al., 1990; also see above). This can now be supplemented by further details.

Pirsonia guinardiae has a relatively long lifetime of up to 14 days. In heavily infected cultures, flagellates become temporarily immobile. When no more hosts are available,

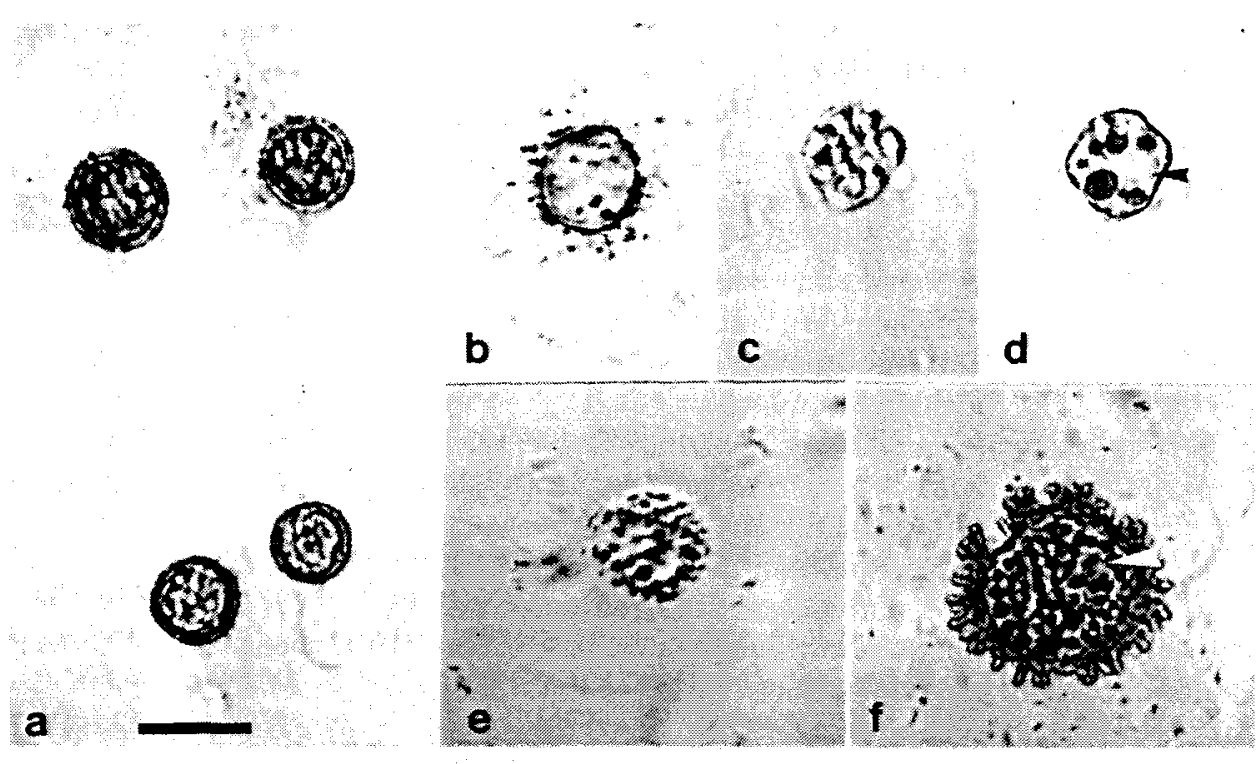

Fig. 1. Pirsonia guinardiae. Resting cysts at the bottom of the Petri dish. a: Cysts with slightly granular contents. b: Empty cyst. c: Encysting FMC with large refractive granules. d: Same cell 2 h 20 min later; refractive granules enlarged by fusion, nucleus (arrowhead). e: Large, flat cyst with developing cyst wall. Note the fine structures radiating from the cell. f: Large, flat cyst containing many refractive granules, surrounded by brown, warty projections; nucleus (arrowhead). 
they assemble on the bottom of the Petri dish or, more preferentially, in empty frustules of the host.

In old cultures, more frequently in $F / 2$ than in Met 44 medium, resting cysts are formed on the bottom of the Petri dish or by adhering to an empty frustule. One cell forms one cyst. The cysts are globular (Fig. 1a) and 5-10 $\mu \mathrm{m}$ in diameter. They are filled with refractive granules of reserve material and enveloped by a red-brown to dark-brown cyst wall. In laboratory cultures the resting cysts persist for at least ten months. Empty cysts have been observed (Fig. 1b), but the excystment process has not been observed.

Pirsonia guinardiae also forms "flat cysts", which may reach a diameter of more than $15 \mu \mathrm{m}$. Frequently they are surrounded by a "halo" of brown warts (Fig. 1f) which seem to develop from fine, hair-like projections from the encysting cell (Fig. 1e). The flat cysts contain very large refractive granules which arise by the fusion of smaller ones (Figs 1c, d). The flat cysts seem to degenerate soon.

Table 1. Host range of Pirsonia species. First group of diatoms: primary hosts ("host"). Second group: further results of feeding experiments or observations in raw cultures. Data from feeding experiments: ++ well suitable as host; + less suitable as host but growth possible; ( + ) attachment, occasionally weak growth; 0 attachment but no growth; - - not attacked. Observations in raw cultures: - not attacked; n.d. not determined

\begin{tabular}{|c|c|c|c|c|c|c|}
\hline Diatom & $\begin{array}{c}P . \\
\text { diadema }\end{array}$ & $\begin{array}{c}P . \\
\text { eucampiae }\end{array}$ & $\begin{array}{c}P . \\
\text { guinardiae }\end{array}$ & $\begin{array}{c}P . \\
\text { verrucosa }\end{array}$ & $\begin{array}{c}P . \\
\text { formosa }\end{array}$ & $\begin{array}{c}P . \\
\text { mucosa }\end{array}$ \\
\hline Coscinodiscus granii & host & -- & -- & -- & 0 & -- \\
\hline Eucampia zodiacus & -- & host & -- & -- & ++ & -- \\
\hline Guinardia flaccida & -- & -- & host & -- & + & 0 \\
\hline Rhizosolenia delicatula & -- & - & + & host & ++ & + \\
\hline$R$. setigera & -- & -- & -- & -- & host & + \\
\hline R. shrubsolei & -- & -- & -- & n.d. & ++ & host \\
\hline Actinoptychus senarius & -- & n.d. & -- & n.d & -- & n.d. \\
\hline Cerataulina pelagica & -- & + & -- & -- & ++ & -- \\
\hline Chaetoceros spp. & -- & -- & -- & n.d. & -- & -- \\
\hline Coscinodiscus concinnus & + & -- & -- & n.d. & -- & -- \\
\hline C. wailesii & ++ & - & -- & -- & -- & -- \\
\hline Detonula pumila & -- & -- & -- & n.d. & -- & -- \\
\hline Lauderia annulata & -- & + & -- & n.d. & -- & -- \\
\hline Leptocylindrus danicus & -- & - & -- & -- & ++ & n.d. \\
\hline Odontella obtusa & -- & n.d. & - & - & 0 & - \\
\hline Rhizosolenia pungens & -- & -- & -- & n.d. & + & -- \\
\hline R. stolterfothii & -- & -- & -- & -- & + & n.d. \\
\hline Stephanopyxis turris & -- & n.d. & -- & n.d. & $(+)$ & -- \\
\hline $\begin{array}{l}\text { Thalassionema } \\
\text { nitzschioides }\end{array}$ & -- & -- & -- & n.d. & + & -- \\
\hline Thalassiosira gravida & -- & n.d. & - & n.d. & -- & -- \\
\hline$T \cdot$ punctigera & -- & -- & -- & n.d. & -- & -- \\
\hline T. rotula & -- & - & -- & -- & -- & -- \\
\hline
\end{tabular}




\section{Pirsonia verrucosa Kühn sp. nov.}

(Figs $2 \mathrm{a}-\mathrm{g}$ )

D i a g n o s is : Flagellates ca $8 \mu \mathrm{m}$ long, ca $3 \mu \mathrm{m}$ wide. Anterior flagellum ca $10 \mu \mathrm{m}$, posterior ca $15 \mu \mathrm{m}$ long. Flagella are retained for some hours after attachment to a host cell. Primary auxosome up to $9 \times 11 \mu \mathrm{m}$ in diameter. Primary and secondary auxosomes very warty. Flagella developed already on flagellate mother cells. During further development - loss of warty structure. On Rhizosolenia delicatula.

Type locality: North Sea, near Helgoland.

Holotype: Fig. 2c.

Further observations: Pirsonia verrucosa was isolated from Rhizosolenia delicatula in August 1993 in the North Sea near Helgoland at a water temperature of $16-17^{\circ} \mathrm{C}$ and was observed at the same time in the Wadden Sea near List (Sylt). We failed to maintain the culture for a longer time. This was probably due to contamination with a flagellate like Cafeteria which has been reported to cause mortality in cultures of various diatoms (Nygaard \& Hessen, 1994). Therefore, studies on the host range (Table 1), generation times, etc. are still incomplete.

The development is shown in Figures 2a-e. The flagellates attach themselves preferentially to the edges of the valves (Figs $2 a-d, g, h$ ), but occasionally also in the girdle region. After attachment the flagella are retained for a long time. Even after formation of a trophosome they sometimes retain motility, thus pulling host cells through the medium. Frequently, chains of $R$. delicatula become separated into single cells by the infection. Occasionally, one flagellate infects two adjacent diatom cells and forms a trophosome in each host cell (Fig. $2 \mathrm{~g}$ ). Sometimes, the trophosomes of two individuals infecting the same diatom fuse (Fig. 2f).

The growing primary auxosome (Fig. 2a) and especially the secondary auxosomes are warty due to small pseudopodium-like processes each containing a refractive granule (Figs 2a-d). The name verrucosa was chosen to denote this distinguishing feature. The flagella do not disappear until just before the first division which is longitudinal and equal (Fig. 2b). Usually 2 or 4 secondary auxosomes are formed before FMCs develop. Frequently, the FMCs form 4 flagella before the maturation divisions set in (Fig. 2c), and these divisions can take place when the FMCs are still loosely attached to the host cell (Fig. 2d) or are at the bottom of the Petri dish (Fig. 2e). In this stage the warty structure disappears. 

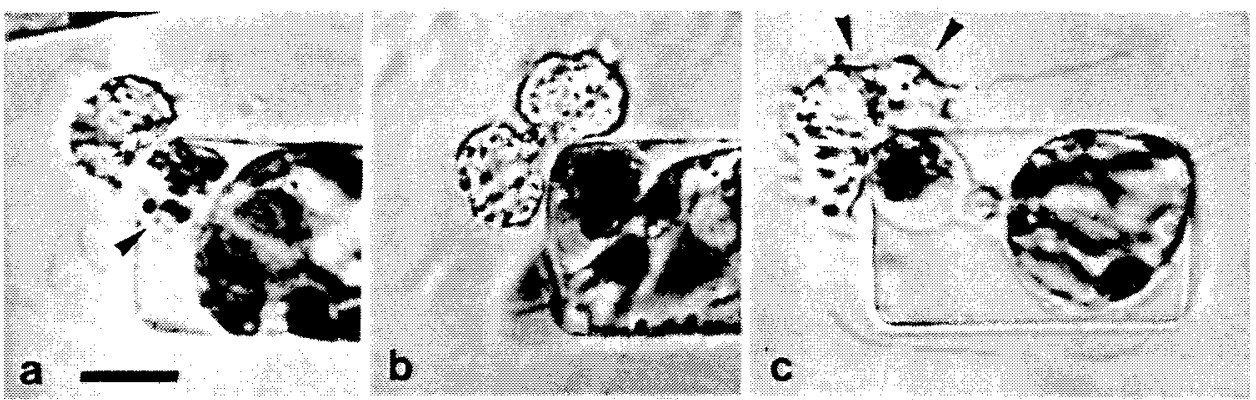

a

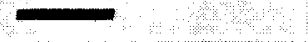

b

\section{c}
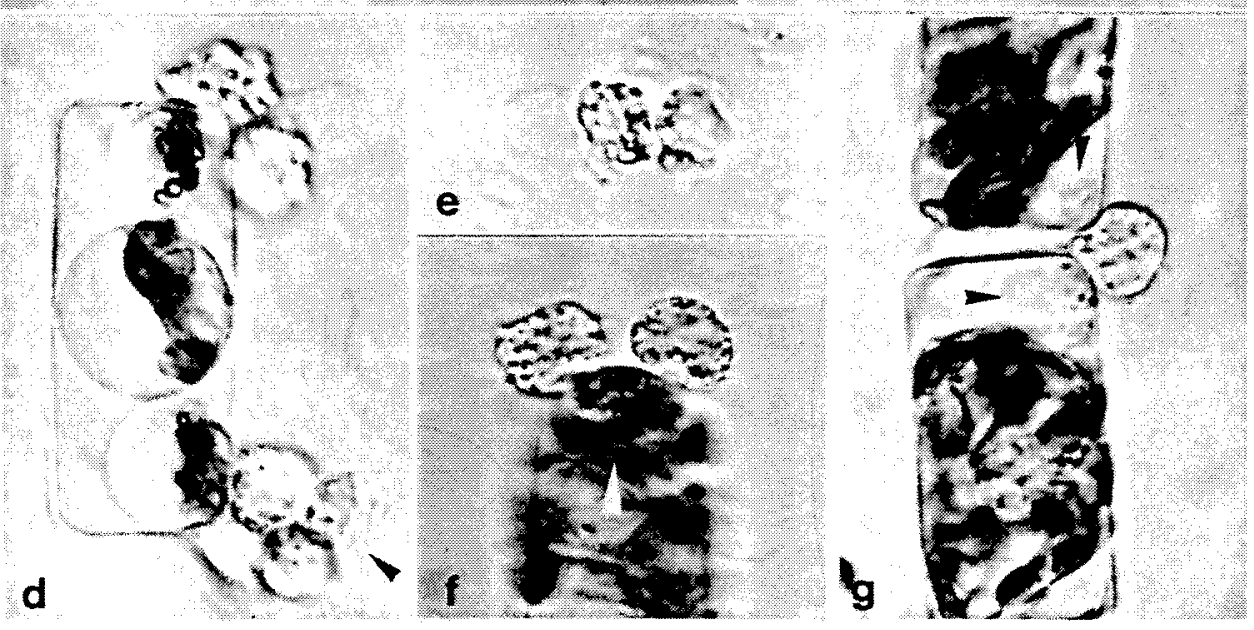

Fig. 2. Pirsonia verrucosa on Rhizosolenia delicatula. a: Primary auxosome, attached to the edge of a valve, becoming warty; trophosome (arrowhead) with partly digested host material. b: Longitudinal division of the primary auxosome. c: Secondary auxosomes, becoming FMCs, very warty, short flagella are visible (arrowheads). d: Two cells of $P$. verrucosa attached to one host cell; upper group with very warty auxosomes, lower group with developing flagella (arrowheads). e: Newly divided FMC at the bottom of the Petri dish; developing flagella. f: Two auxosomes with a common (fused) trophosome (white arrowhead). g: Auxosome connected with two host cells each containing a trophosome (arrowheads). Scale bar $=10 \mu \mathrm{m}$ (in 2a) 


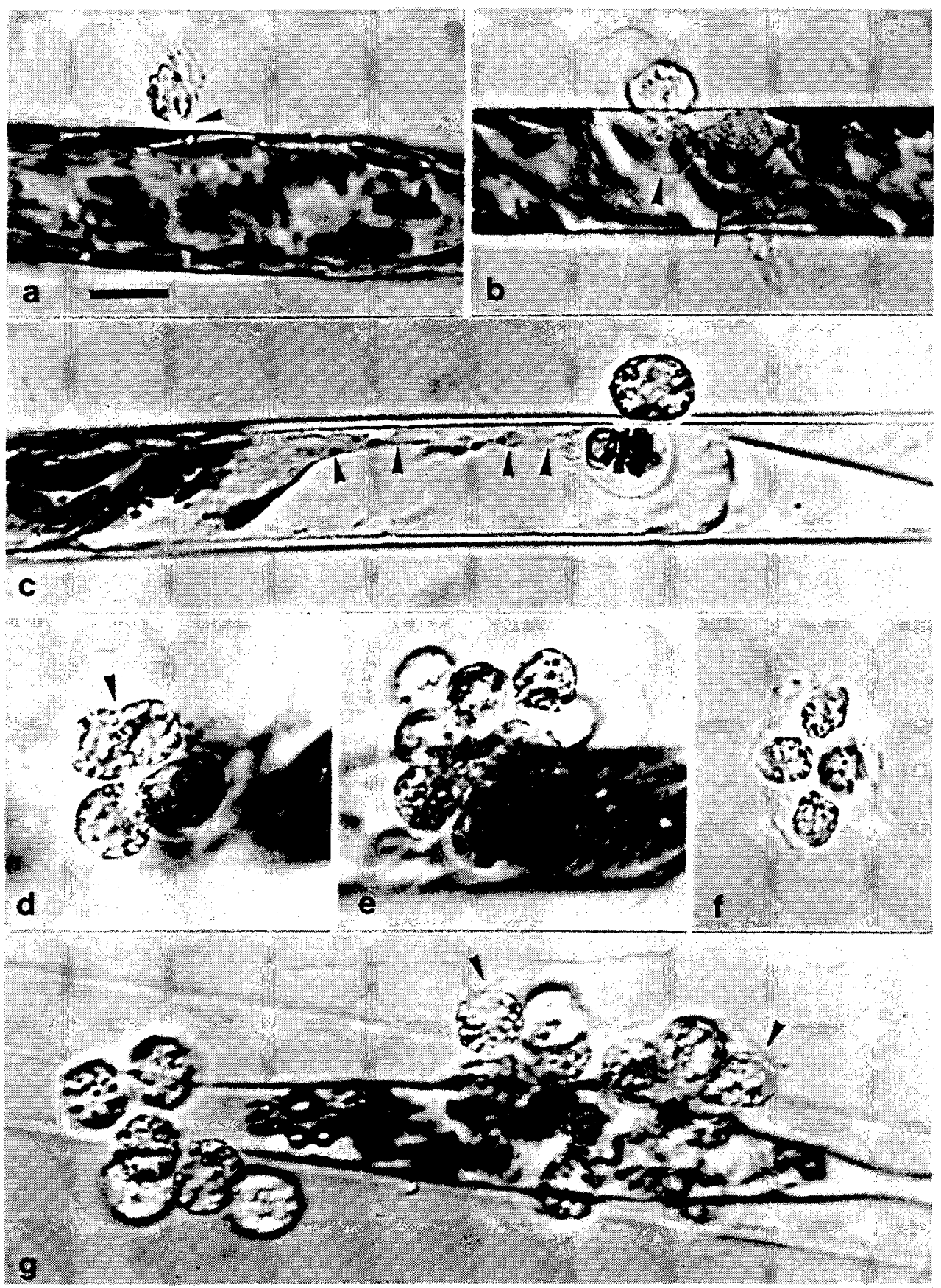


Pirsonia formosa Kühn sp. nov.

(Figs 3a-g)

Di a g n o s is : Flagellates $7-8 \mu \mathrm{m}$ long, 5-6 $\mu \mathrm{m}$ wide. Anterior flagellum $15-18 \mu \mathrm{m}$, posterior flagellum 25-30 $\mu \mathrm{m}$ long. Flagella disappear soon after attachment of the cell to a host. Primary auxosomes globular, up to $13 \mu \mathrm{m}$ in diameter. First divisions equal and longitudinal, frequently giving rise to 8 secondary auxosomes. On Rhizosolenia setigera, Leptocylindrus danicus, Cerataulina pelagica.

Type locality: North Sea, near Helgoland.

Holotype: Fig. 3e.

Further observations: Pirsonia formosa has a broad host range (Table 1). It was isolated from Rhizosolenia setigera in August 1993 in the North Sea, near Helgoland, at a water temperature of $16-17^{\circ} \mathrm{C}$. It was further observed on March 3pth, 1994 in the Wadden Sea near List (Sylt) infecting $R$. setigera which was very abundant at the time. Probably, $P$. formosa was first seen in August 1988 when a flagellate unknown at the time infected R. shrubsolei (M. Elbrächter, pers. comm.).

Experiments showed that $P$. formosa also infects successfully Eucampia zodiacus, Rhizosolenia pungens, $R$. stolterfothii and Guinardia flaccida (Table 1). The size of the diatom infected determines the growth of the parasite; a small diatom, e.g. Thalassionema nitzschioides, when infected, allows growth of Pirsonia of up to two divisions only. While vegetative cells of Stephanopyxis turris became weakly infected, resting spores were not attacked at all. Odontella obtusa was not infected, but $P$. formosa flagellates attached themselves to naked protoplasts of this diatom. In over-infected cultures, starving flagellates also attached themselves to empty frustules of $R$. setigera.

The infection and development process is shown in Figures 3a-g. All observations have been made with $R$. setigera as host. The flagellates attach themselves to the frustule preferentially in the girdle region (Fig. 3a). Soon after attachment and invasion the frustules of the flagella disappear (Fig. 3b), presumably by retraction. The primary auxosome is globular (Fig. 3c). The first divisions are usually longitudinal (Fig. 3d), and finally about 8 secondary auxosomes are formed (Fig. 3e). The species name "formosa" (= beautiful) refers to the appearance of the resulting group of round, almost equally sized cells. The connection with the trophosome is not visible at this stage. The FMCs mature synchronously. Frequently, a FMC develops four short flagella of different lengths (Fig. $3 \mathrm{~g}$ ). After division, the lengths of the posterior flagella may differ in the two daughter cells. The posterior flagellum seems to elongate first, at a rate of about $2 \mu \mathrm{m}$ per 10 min. A FMC generally divides twice (Fig. 3f).

In heavily infected cells the adjacent trophosomes of two individuals may fuse (not shown). The generation time is $24-26 \mathrm{~h}$, and the infective lifetime is $3-4$ days.

Fig. 3. Pirsonia formosa on Rhizosolenia setigera. a: Newly attached flagellate, distinct basal foot (arrowhead): flagella coiled at the apical pole. b: Young primary auxosome with trophosome (arrowhead), ingesting the host nucleus (arrow). c: Primary auxosome, trophosome with digested chloroplasts, further portions of the host cytoplasm becoming ingested (arrowheads). d: Group of secondary auxosomes, one of which is dividing (arrowhead). e: Group of equally sized FMCs (and secondary auxosomes?). f: A FMC has divided twice: 4 developing flagellates. $\mathrm{g}$ : Two groups of FMCs, developing flagella (arrowheads). Scale bar $=10 \mu \mathrm{m}$ (in 3a) 

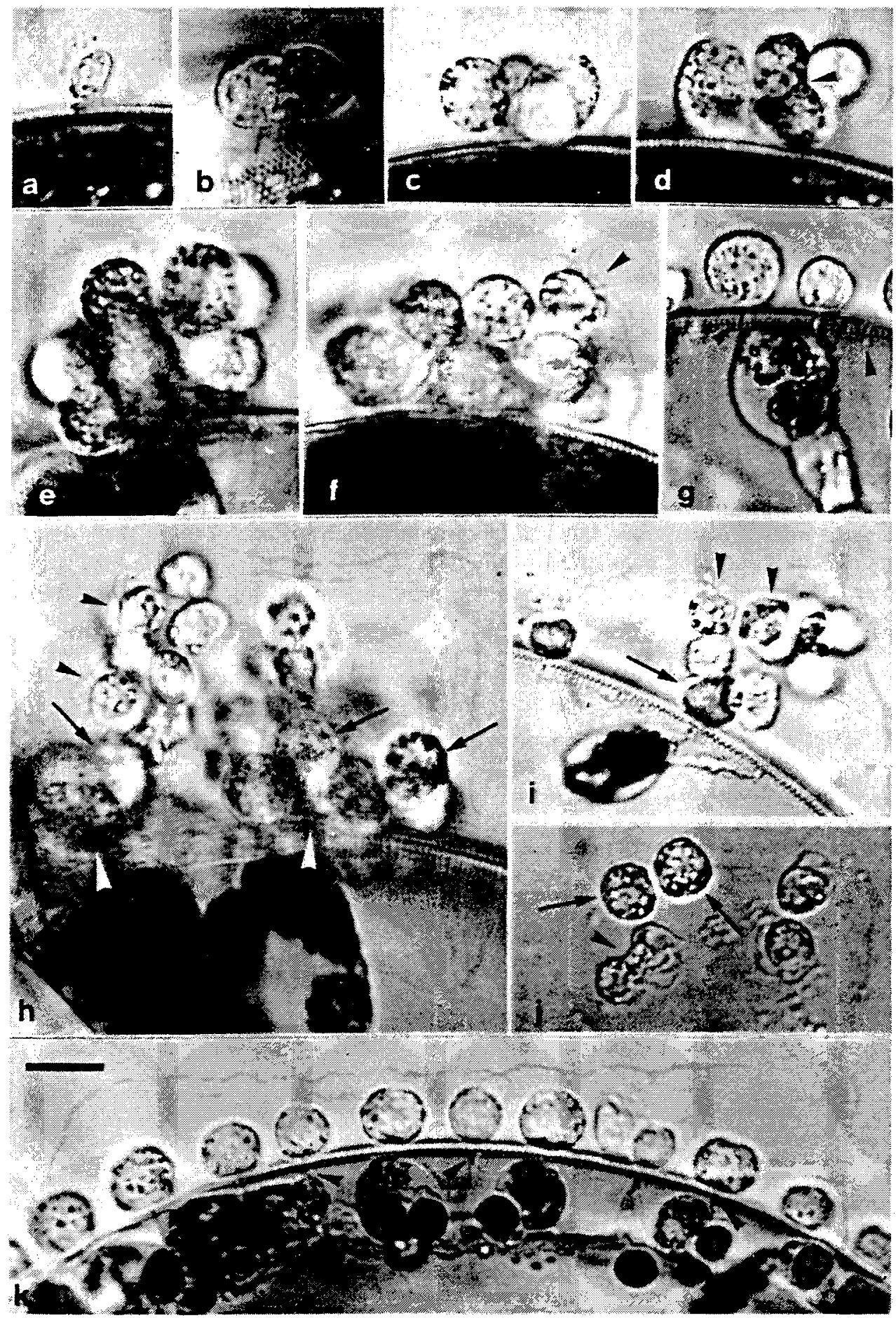


\section{Pirsonia diadema Kühn sp. nov.}

(Figs $4 a-k$ )

D i a g n o s i s : Flagellates 8-10 $\mu \mathrm{m}$ long, 3-4 $\mu \mathrm{m}$ wide. Anterior flagellum 16-18 $\mu \mathrm{m}$, posterior flagellum 35-40 $\mu \mathrm{m}$ long. Flagella disappear soon after attachment to a host cell. Primary auxosome apple-like in shape, up to $10 \mu \mathrm{m}$ in diameter. First divisions generally longitudinal, but unequal "transversal" divisions set in relatively soon in development. Development asynchronous. Vegetative host cells are invaded only through rimoportulae of the valves. On Coscinodiscus granii and C. wailesii.

Type locality: North Sea, near Helgoland.

Holotype: Fig. 4 h.

Further observations: Pirsonia diadema was isolated from Coscinodiscus granii in September 1992 in the North Sea near Helgoland at a water temperature of $16-17^{\circ} \mathrm{C}$. At the time, it was also infecting $C$. wailesii. Infections of $C$. granii and $C$. wailesii were observed at the same site in August 1993. Experiments showed that $C$. concinnus is also successfully attacked (Table 1). C. wailesii is much more attractive for infection than C. granii or C. concinnus (the latter is only weakly attractive). In cultures of C. granii some cells show multiple infections, while other cells remain unattacked for a very long time. Spermatogonangia, auxospores and initial cells of $C$. granii are also attacked. The maximum swimming speed of the flagellates is about $60-70 \mu \mathrm{m} \mathrm{s}^{-1}$.

The infection and development process is shown in Figures $4 \mathrm{a}-\mathrm{j}$. The flagellates attach themselves exclusively to the rimoportulae (Figs $4 \mathrm{~g}, \mathrm{k}$ ). In Coscinodiscus granii the rimoportulae form a dense ring at the margin of the valve, whereas in $C$. wailesii the rimoportulae are arranged in two marginal rings, and additional rimoportulae are scattered on the valve face. The flagellates form a broad foot (Fig. 4a) and invade through the rimoportulae into the diatom cell. In heavily infected cultures almost every rimoportula is occupied by a flagellate which gives the appearance of a diadem (Fig. 4k). Therefore the species name "diadema" was chosen.

After attachment, the flagella coil around the anterior pole (Fig. 4a) and soon disappear. The auxosome starts to grow after about one hour. At this time the host chloroplasts have begun to migrate systrophically towards the trophosome. The first divisions of the auxosome are generally longitudinal and equal (Fig. $4 \mathrm{~b}$ ). Figure $4 \mathrm{c}$ shows a group of four globular auxosomes. The next divisions are usually "transverse" (with respect to the longitudinal axis of the cell body) (Figs $4 \mathrm{~d}$, e). The resulting secondary auxosomes and FMCs divide and mature asynchronously (Fig. 4f). The outer cells of a

Fig. 4. Pirsonia diadema on Coscinodiscus granii. a: Newly attached flagellate, broad basal foot, flagella coiled at the apical pole. b: Dividing primary auxosome. c: Group of 4 secondary auxosomes. $\mathrm{d}$ : Group of dividing secondary auxosomes, giving rise to FMCs i division plane (arrowhead) is transverse to the "longitudinal axis" of the cell. e: Group of secondary auxosomes and FMCs. f: Group of secondary auxosomes and FMCs, one with 4 developing flagella (arrowhead). $g$ : Two auxosomes with fused trophosomes in an over-infected host cell; note the rimoportulae on the Coscinodiscus valve (arrowheads). h: Two large groups of secondary auxosomes (white arrowheads), FMCs (arrows) and developing flagellates (arrowheads). i: Small group of FMCs (arrow) and developing flagellates (arrowheads) with a small trophosome in an over-infected host cell. j: Newly formed flagellates and FMCs (arrows) at the bottom of the Petri dish, one dividing FMC (arrowhead).

$\mathrm{k}$ : Primary auxosomes at the rimoportulae (arrowheads) of an over-infected Coscinodiscus cell. 


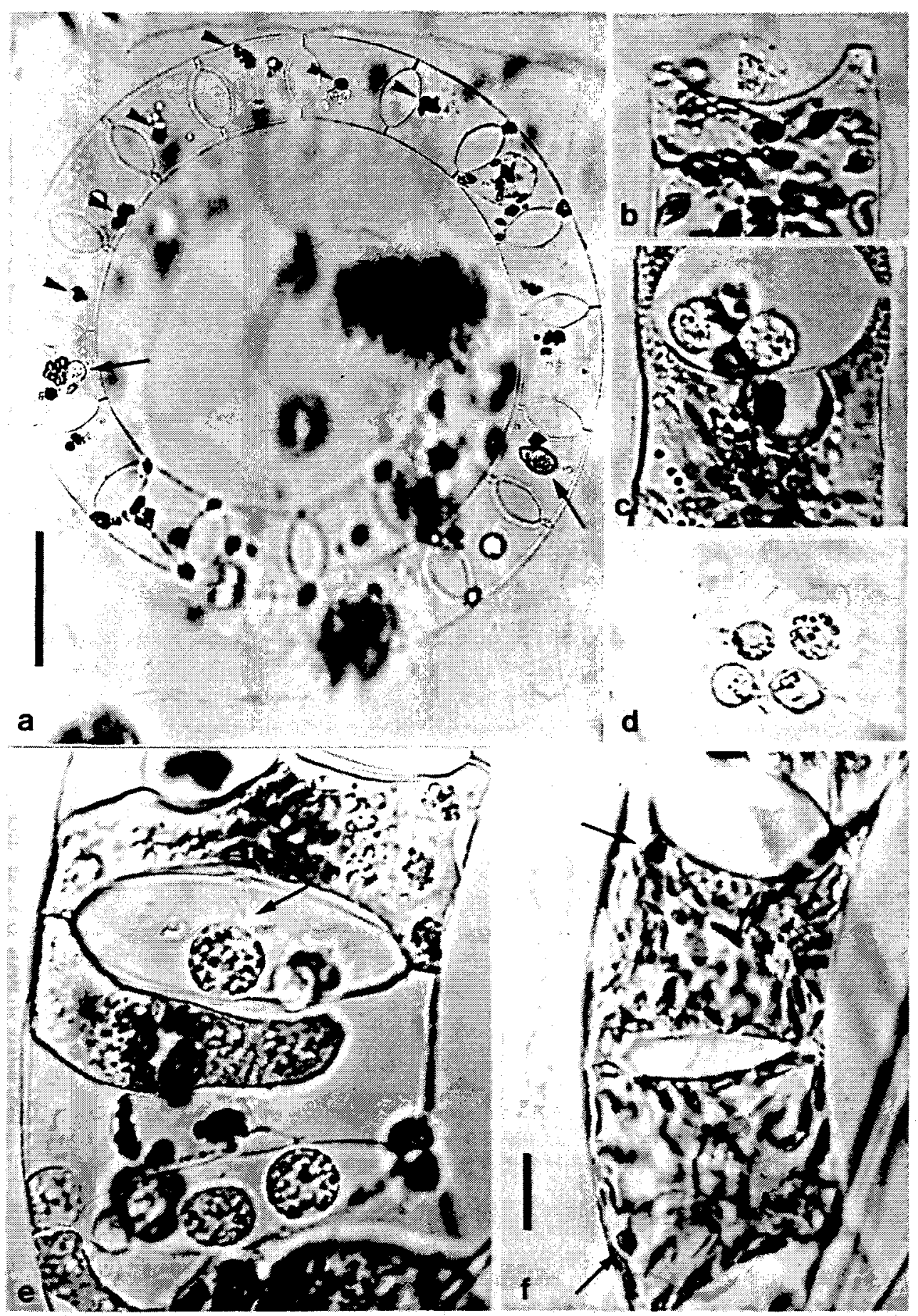


group may serve as FMCs with 4 short flagella, while the inner ones are still secondary auxosomes (Fig. 4h). Division and maturation take place in cells loosely attached to the group (Fig. $4 \mathrm{~h}$ ) or at the bottom of the Petri dish (Fig. 4j). More than 30 flagellates may be formed from a single infection, but fewer when the food supply is insufficient as in overinfected diatoms (Fig. 4i).

In heavily infected cultures the trophosomes of several adjacent individuals frequently fuse (Fig. $4 \mathrm{~g}$ ).

The generation time of $P$. diadema is about $24 \mathrm{~h}$, and the infective phase lasts for up to 3 days.

$$
\text { Pirsonia eucampiae Kühn et Schnepf sp. nov. }
$$

(Figs 5a, f)

Diagnosis: Flagellates 7-9 $\mu \mathrm{m}$ long, 4-5 $\mu \mathrm{m}$ wide. Anterior flagellum ca $15 \mu \mathrm{m}$, posterior flagellum ca $45 \mu \mathrm{m}$ long. Flagella not completely retracted during auxosome development but present during the whole development. Primary auxosome globular, up to $12 \mu \mathrm{m}$ in diameter. Longitudinal divisions generally give rise to four flagellate mother cells which divide once. On Eucampia zodiacus.

Type locality: North Sea, Wadden Sea near List (Sylt).

Holotype: Fig. Se.

Further observations: Pirsonia eucampiae was isolated from Eucampia zodiacus in August 1994 from the Wadden Sea near List (Sylt) at a water temperature of $17^{\circ} \mathrm{C}$. A bloom of E. zodiacus was present at the time which was followed by mass development of $P$. eucampiae. Up to $50 \%$ of the host cells were found to be attacked or killed by $P$. eucampiae. In Figure 5a, all cells in a chain of Eucampia have been killed by $P$. eucampiae, as indicated by the brown residual bodies, the remnants of the trophosomes, in each cell. P. eucampiae also attacks Cerataulina pelagica and Leptocylindrus danicus (Table 1).

The development is shown in Figures 5b-e. The flagellates attach themselves preferentially to the central region of the valve (Figs $5 b, c)$, where the single rimoportula is located, occasionally also to the edge of the valve or the girdle region. Multiple infections are rare.

The primary auxosome becomes globular in shape (Fig. 5e). The flagella are not completely retracted and remain visible during development of secondary auxosomes and FMCs (Fig. 5e). Generally 4 FMCs are formed which seem to divide once. Figure $5 \mathrm{~d}$ shows a group of newly formed flagellates with developing flagella.

The trophosome is relatively small (Fig. 5c). Chloroplasts and cytoplasm of the diatom cell are phagocytized, but the host nucleus frequently does not move towards the trophosome and thus escapes ingestion (Fig. 5a). Large Eucampia cells may occasionally overcome an attack by $P$. eucampiae. They seem to recover and regain a normal

Fig. 5. Pirsonia eucampiae on Eucampia zodiacus. a: Chain of dead Eucampia cells, plankton sample. The brown residual bodies (arrowheads) indicate that the cells have been killed by $P$. eucampiae; some nuclei are not ingested (arrows). b: Flagellate attached to the centre of the valve, flagella apically coiled. c: Group of 4 secondary auxosomes becoming FMCs. d: Group of newly formed flagellates with developing flagella. e: Part of a Eucampia chain with large primary auxosome, the flagella are visible in one auxosome (arrow). f: Part of a Eucampia chain; 2 cells recovered from $P$. eucampiae attack, as indicated by the residual bodies (arrows). Scale bar $=50 \mu \mathrm{m}$ (for $5 \mathrm{a}$ ); scale bar $=10 \mu \mathrm{m}$ (in 5 f for Fig. $5 \mathrm{~b}-\mathrm{f}$ ) 


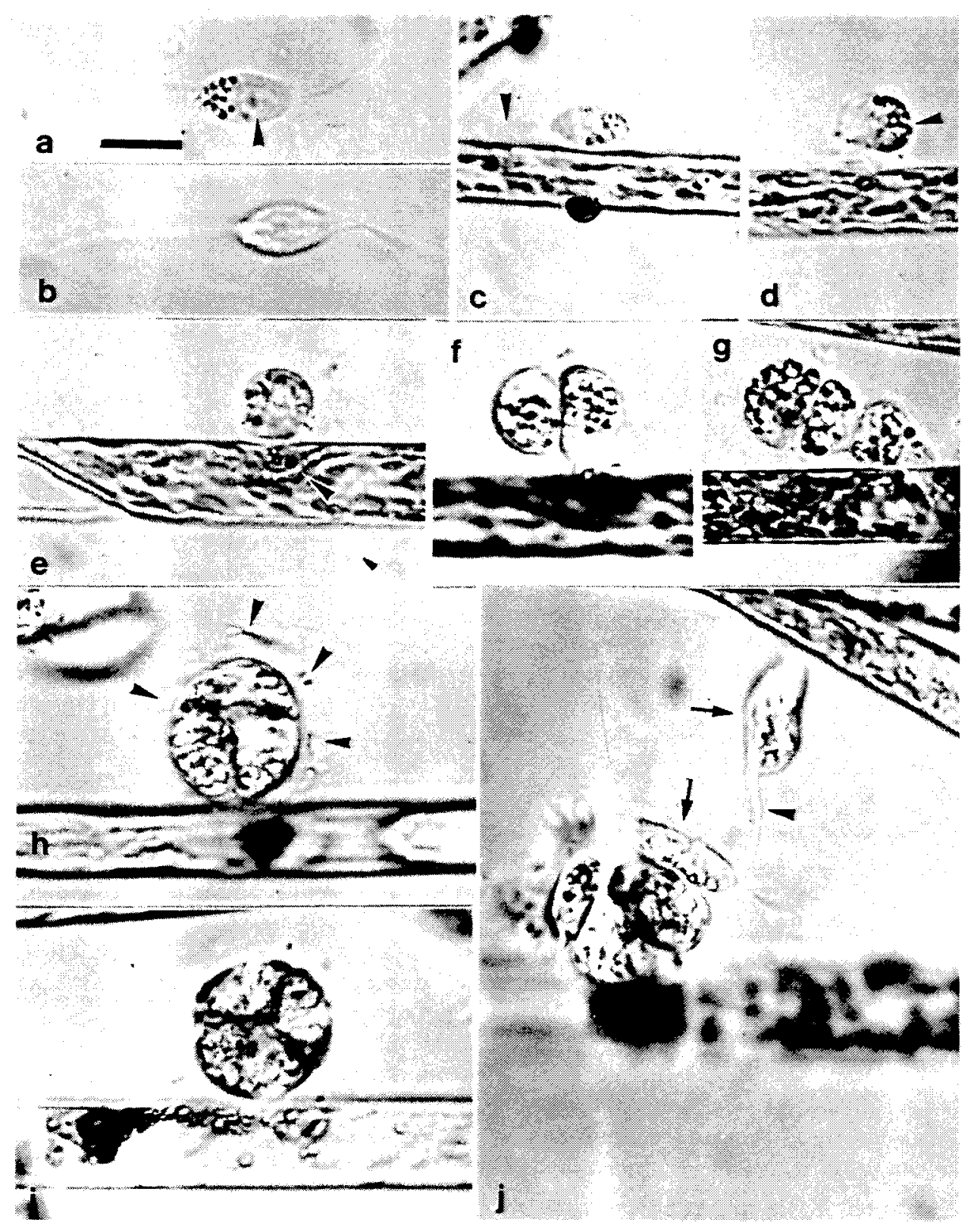


appearance. Only a dark-brownish residual body left behind as a remnant of a trophosome is a reminiscence of the former infection (Fig. 5f).

Pirsonia mucosa Drebes sp. nov.

\section{(Figs 6a-i)}

Diagnosis: Flagellates $12-14 \mu \mathrm{m}$ long, 5-7 $\mu \mathrm{m}$ wide. Anterior flagellum 10-12 $\mu \mathrm{m}$, posterior flagellum 26-32 $\mu \mathrm{m}$ long. Flagella insert in a median position and are relatively stiff. Movement is mainly a slow gliding rather than swimming. Flagellates attach themselves with their lateral side or even subapically. Generally only one auxosome, up to $18 \mu \mathrm{m}$ in diameter. It remains connected to the trophosome. Division pattern variable, resulting in a morula-shaped accumulation of frequently not more than 4 flagellate mother cells, surounded by a common mucilaginous envelope. On Rhizosolenia shrubsolei.

Type locality: North Sea, Wadden Sea near List (Sylt).

Holotype: Fig. 6 j.

Further observations: Pirsonia mucosa was isolated from Rhizosolenia shrubsolei on November 11th, 1993 from the Wadden Sea near List (Sylt) at a water temperature of $6^{\circ} \mathrm{C}$. Although R. shrubsolei was abundant off List in May and June 1994, infections by $P$. mucosa could not be detected. $P$. mucosa also feeds on $R$. delicatula and R. setigera (Table 1). *

Figure 6 a shows a flagellate with its stiff flagella inserting ventrally in the middle of the cell or even in a submedian position (Fig. 6b). In general, the flagellates move about 2-4 um per second, more or less gliding rather than swimming, with their ventral side along the substrate. During this movement, the anterior flagellar tip touches the host cell, while the posterior flagellum remains almost motionless (Fig. 6c).

The development is shown in Figures $6 \mathrm{a}-\mathrm{j}$. The flagellates attach themselves to the girdle region, preferably near the valves (Fig. 6e). They form an unusually broad foot (up to $2 \mu \mathrm{m}$ in diameter) which is, in contrast to other Pirsonia species, situated somewhat laterally (Fig. 6d) or even subapically (Fig. 6e). The flagella disappear soon after attachment to the cell. Cells of $R$. shrubsolei show a conspicuous cytoplasmic streaming which can continue for some time also in infected cells.

- Note added in proof: In September 1995 we found Pirsonia mucosa feeding on Cerataulina pelagica. After isolation, this strain was observed infecting Rhizosolenia shrubsolei in the characteristic manner, as well as Eucampia zodiacus and Chaetoceras decipiens Cleve.

Fig. 6. Pirsonia mucosa on Rhizosolenia shrubsolei. a: Flagellate gliding at the bottom of the Petri dish: anterior flagellum right, nucleus (arrowhead); refractive granules of reserve material in the posterior part of the cell. b: As Fig. 6a, flagella insert in an almost median position, anterior flagellum right. c: Flagellate, touching a host cell with the tip of the anterior flagellum (arrowhead). d: Newly attached $P$. mucosa, a broad foot has been formed laterally, posterior part of the cell with many refractive granules (arrowhead). e: Developing primary auxosomes with a small trophosome (arrowhead); the refractive granules in the posterior part of the cell indicate that the flagellate has attached itself near its apical end. f: After the first division, a FMC is cut off which is no longer connected with the trophosome. $\mathrm{g}-\mathrm{i}$ : Groups of 3-4 cells, varying in arrangement: only one cell seems to be connected with the trophosome. $\mathrm{h}$ : The mucilaginous coat is lined by bacteria (arrowheads) and thus more readly visible. j: Group of cells with two newly detached flagellates (arrows), the proximal part of the posterior flagellum of one flagellate is very thick (arrowhead). Scale bar $=10 \mu \mathrm{m}$ (in 6a) 
The auxosome grows to a size of $15-18 \mu \mathrm{m}$. The division pattern is highly variable. The first division is more or less longitudinal, though it may appear to be transverse with respect to the diatom frustule. In consequence, only one of the resulting daughter cells remains connected with the trophosome (Figs $6 f, g$ ), so that a further secondary auxosome is not formed. The auxosome continues to divide. The developing cells form a globular, morula-like group in various arrangements (Figs $6 h, i, j$ ), in which only one cell seems to remain connected to the trophosome. This cell group is usually coated with mucilage: seen best when bacteria are attached (Fig. 6h). This character was name-giving. Generally about 8 flagellates arise from 4 FMCs which do not mature synchronously (Fig. 6j). The flagella begin to develop early, even in the FMCs. Initially, the posterior flagellum is very thick and has the appearance of a cytoplasmic tail (Fig: 6j).

The life cycle takes about $24 \mathrm{~h}$.

\section{DISCUSSION}

Very little is known about the interaction between heterotrophic nanoflagellates and diatoms in aquatic ecosystems. Heterotrophic nanoflagellates have been generally considered to be grazers of bacteria and picophytoplankton (Sherr et al., 1991; Hall et al., 1993). Reports on nanoflagellates feeding on diatoms many times their size are scarce (Suttle et al., 1986). This lack of information could be primarily due to the fact that with the traditional sampling and preservation methods many colourless flagellates escape notice (Lovejoy et al., 1993). Very often it proves impossible to identify from preserved field samples the kinds of organisms that attack the diatoms. Identification frequently requires living material, or even cultures, in order to observe the developmental stages and/or host range.

There are nevertheless several reports that infection rates of marine diatoms by a variety of parasitic Protista can be very high. This was observed for the dinoflagellate Paulsenella Chatton feeding on Streptotheca thamesis Shrubsole (Drebes \& Schnepf, 1982, 1988). Up to $92 \%$ of the populations of Coscinodiscus and Palmeria have been found to be infected by the oomycete Lagenisma coscinodisci Drebes (Drebes, 1968; Grahame, 1976; Wetsteyn \& Peperzak, 1991). Careful observation of living material often results in finding new parasites of diatoms, e.g. a phagotrophic flagellate frequently feeding on Rhizosolenia delicatula (Drebes et al., in prep.), or Phagomyxa algarum Karling, infecting Bellerochea malleus (Brightwell) Heurck (Schnepf, 1994). Schnepf et al. (1990) observed that up to $30 \%$ of the population of Guinardia flaccida were infected by Pirsonia guinardiae, and we found up to $40-50 \%$ of the Eucampia zodiacus cells being killed by Pirsonia eucampiae.

There can be no doubt that the five newly detected flagellates belong to the genus Pirsonia. In all details they fit the diagnosis of the genus (see Schnepf et al., 1990). They all develop in the same way which is now described in more detail. A certain exception is $P$. mucosa. In this species the flagella are not inserted subapically but in the middle of the cell or even submedianly.

The newly recognized Pirsonia-like flagellates are not merely host races but have to be considered distinct species. They differ from each other not only in their host range but also in the size and shape of the flagellates and auxosome and in details of development. 
P. guinardiae occurs in two different types which are distinguished morphologically and in their development (Schnepf et al., 1990).

$P$. mucosa has a unique position. The flagellates of this species differ in their mode of movement, in the angle of attachment to the diatom frustule, and consequently in the pattern of cell division.

The occurrence of the globular resting cysts may indicate how $P$. guinardiae overcomes unfavourable environmental conditions. Occasionally observed excystment stages are perhaps due to the unnatural conditions in very old cultures.

It is questionable whether the "flat cysts" are true resting cells or represent rather a special, artificial form of "dying FMCs". Their size and the high contents of refractive granules which partially fuse during encystment indicate that they arise from motile FMCs and become flattened during the attachment to the bottom of the Petri dish.

The six Pirsonia species together attack a broad range of common, centric diatoms, but each lives only on one or a few host species. On the one hand, it is advantageous for phytoplankton feeders to be omnivorous, thereby improving their chances to get supplied with enough food. For a flagellate like Pirsonia it may be, on the other hand, a disadvantage when it is attracted by too many different diatom species or other organisms (see below).

It is generally assumed that diatoms larger than 30-50 $\mu \mathrm{m}$ are captured less by crustacean zooplankton than small diatoms are (Sommer, 1987). Roy et al. (1989) reported that the large size of Coscinodiscus wailesii resulted in inefficient feeding by Calanus helgolandicus Claus and Temora longicornis Müller.

For Pirsonia species, however, a large diatom represents a quantitatively excellent food source, e.g. Coscinodiscus wailesii - with a diameter of up to about $500 \mu \mathrm{m}$ - for $P$. diadema, which measures only $4 \times 10 \mu \mathrm{m}$. It costs a lot of time, energy and biomaterial to find the host and to produce the trophosome. It is thus inefficient to feed on small host cells. In this case more than one diatom has to be attacked in order to ingest enough food for offspring to be produced. An example of this inefficiency is demonstrated by P. formosa on Thalassionema nitzschioides. In consequence, the evolutionary strategy of a Pirsonia or a similar organism has to be to exclude small diatoms as possible hosts and to become a specialist in host range.

Before a trophosome can be formed, the diatom frustule has to be penetrated. Most Pirsonia species attach themselves preferentially to the girdle region. The cingulum is less rigid than the valves, and the pseudopodium can perhaps slip under the overlap between two intercalary bands, as seen in P. guinardiae (Schnepf et al., 1990). In strongly silicified Coscinodiscus cells, Pirsonia diadema uses the numerous rimoportulae as an entrance way. Each Pirsonia species has to find the host specific site where an invasion is possible.

Our observations indicate that Pirsonia species, as well as other parasitic flagellates or fungi (in a wide sense), are important in controlling the composition of marine phytoplankton. As food specialists, they can change the spectrum of diatom species. In reducing the number of individuals of a dominant species they may also affect the phytoplankton biomass.

Acknowledgements. We are grateful to $\mathrm{H}$. Halliger for technical assistance, Dr. M. Elbrächter for valuable discussions, and the Deutsche Forschungsgemeinschaft for support. 


\section{LITERATURE CITED}

Cadée, G. C., 1986. Recurrent and changing seasonal patterns in phytoplankton of the westernmost inlet of the Dutch Wadden Sea from 1969 to 1985. - Mar. Biol. 93, 281-289.

Drebes, G., 1968. Lagenisma coscinodisci gen. nov., spec. nov., ein Vertreter der Lagenidiales in der marinen Diatomee Coscinodiscus. - Veröff. Inst. Meeresforsch. Bremerh. Sonderbd 3, 67-70.

Drebes, G. \& Elbrächter, M., 1976. A check-list of planktonic diatoms and dinoflagellates from Helgoland and List (Sylt), German Bight. - Botanica mar. 19, 75-83.

Drebes, G. \& Schnepf, E., 1982. Phagotrophy and development of Paulsenella cf. chaetoceratis (Dinophyta), an ectoparasite of the diatom Streptotheca thamesis. - Helgoländer Meeresunters. $35,501-515$.

Drebes, G. \& Schnepf, E., 1988. Paulsenella Chatton (Dinophyta), ectoparasites of marine diatoms: development and taxonomy. - Helgoländer Meeresunters. 42, 563-581.

Grahame, E. S., 1976. The occurrence of Lagenisma coscinodisci in Palmeria hardmania from Kingston Harbour, Jamaica. - Br. phycol. J. 11, 57-61.

Guillard, R. R. L. \& Ryther, J. H., 1962. Studies on marine phytoplanktonic diatoms. 1. Cyclotella nana Hustedt and Detonula confervacea (Cleve) Gran. - Can. J. Microbiol. 8, 229-239.

Hall, J. A., Barrett, D. P. \& James, M. R., 1993. The importance of phytoflagellate, heterotrophic flagellate and ciliate grazing of bacteria and picophytoplankton sized prey in a coastal marine environment. - J. Plankt. Res. 15, 1075-1086.

Jacobson, D. M. \& Anderson, D. M., 1986. Thecate heterotrophic dinoflagellates: feeding behaviour and mechanisms. - J. Phycol. 22, 249-258.

Jewson, D. H., Rippley, B. H. \& Gilmore, W. K., 1981. Loss rates from sedimentation, nutrient limitation, and dormancy of a diatom crop. - Limnol. Oceanogr. 26, 1045-1056.

Lovejoy, C., Vincent, W. F., Frenette, J.-J. \& Dodson, J. J., 1993. Microbial gradients in a turbid estuary: application of a new method for protozoan community analysis. - Limnol. Oceanogr. 38, 1295-1303.

Nygaard, K. \& Hessen, D. O., 1994. Diatom kills by flagellates. - Nature, Lond. 367, 520.

Roy, S., Harns, R. P. \& Doulet, S. A., 1989. Inefficient feeding by Calanus helgolandicus and Temora longicornis on Coscinodiscus wailesii: quantitative estimation using chlorophyll-type pigments and effects on dissolved free amino acids. - Mar. Ecol. Progr. Ser. 52, 145-153.

Saedeleer, H. de, 1946. Palisporomonas apodinium n. g., n. sp., Flagellé parasite épibiotique de Diatomées marines, type de la famille des Palisporomonadidae nov. fam. Morphologie et palisporogénèse. - Annls Soc. r. zool. Belg. 57, 90-165.

Schnepf, E., 1994. A Phagomyxa-like endoparasite of the centric marine diatom Bellerochea malleus: a phagotrophic plasmodiophoromycete. - Botanica Acta 107, 374-382.

Schnepf, E. \& Deichgräber, G., 1984. "Myzocytosis", a kind of endocytosis with implications to compartmentation in endosymbiosis: observations in Paulsenella (Dinophyta). - Naturwissenschaften $71,218-219$.

Schnepf, E. \& Elbrächter, M., 1992. Nutritional strategies in dinoflagellates. A review with emphasis on cell biological aspects. - Eur. J. Protistol. 28, 3-24.

Schnepf, E., Drebes, G. \& Elbrächter, M., 1990. Pirsonia guinardiae, gen. et spec. nov.: a parasitic flagellate on the marine diatom Guinardia flaccida with an unusual mode of food uptake. Helgoländer Meeeresunters. 44, 275-293.

Schöne, H. K. \& Schöne, A., 1982. A weakly enriched sea-water medium for ecological studies on marine plankton algae, some examples of its application. - Botanica mar. 25, 117-122.

Sherr, E. B., Sherr, B. F. \& McDaniel, J., 1991. Clearance rates of $6 \mu \mathrm{m}$ fluorescently labeled algae (FLA) by estuarine protozoa: potential grazing impact of flagellates and ciliates. - Mar. Ecol. Progr. Ser. 69, 81-92.

Sommer, U., 1987. Factors controlling the seasonal variation in phytoplankton species composition a case study for a deep, nutrient rich lake. - Prog. phycol. Res. 5, 123-178.

Suttle, C. A., Chan, A. M., Taylor, W. D. \& Harrison, P. J., 1986. Grazing of planktonic diatoms by microflagellates. - J. Plankt. Res. 8, 393-398.

Wetsteyn, L. P. M. J. \& Peperzak, L., 1991. Field observations in the Oosterschelde (The Netherlands) on Coscinodiscus concinnus and Coscinodiscus granii (Bacillariophyceae) infected by the marine fungus Lagenisma coscinodisci (Oomycetes). - Hydrobiol. Bull. 25, 15-21. 